九州大学学術情報リポジトリ

Kyushu University Institutional Repository

\title{
Biosorption of Arsenic from Contaminated Water: Composite of Algae and Fe-Nano Particles
}

\section{Islam Mir Shariful}

Mechanical Engineering Department, Kyushu University

Maamoun, Ibrahim

Water and Environmental Engineering Laboratory, Interdisciplinary Graduate School of Engineering Sciences, Kyushu University

Falyouna, 0mar

Water and Environmental Engineering Laboratory, Interdisciplinary Graduate School of Engineering Sciences, Kyushu University

\section{Elsayed B. Belal}

Agriculture Microbiology, Agriculture Botany Department, Faculty of Agriculture, Kafrelsheikh University

他

https://doi.org/10.5109/4738591

出版情報: Proceedings of International Exchange and Innovation Conference on Engineering \& Sciences (IEICES). 7, pp. 218-223，2021-10-21. 九州大学大学院総合理工学府

バージョン:

権利関係 : 


\title{
Biosorption of Arsenic from Contaminated Water: Composite of Algae and Fe-Nano Particles
}

\author{
Islam Mir Shariful ${ }^{1,2,5}$ Ibrahim Maamoun $^{3}$, Omar Falyouna ${ }^{3}$, Elsayed B. Belal ${ }^{4}$, Osama Eljamal ${ }^{3}$, Bidyut Baran Saha ${ }^{1,2 *}$ \\ ${ }^{1}$ Mechanical Engineering Department, Kyushu University, 744 Motooka, Nishi-ku, Fukuoka 819-0395, Japan, \\ ${ }^{2}$ International Institute for Carbon-Neutral Energy Research (WPI-I I CNER), Kyushu University, 744 Motooka, Nishi-ku, \\ Fukuoka 819-0395, Japan. \\ ${ }^{3}$ Water and Environmental Engineering Laboratory, Interdisciplinary Graduate School of Engineering Sciences, \\ Kyushu University, 6-1 Kasuga-koen, Kasuga, Fukuoka, 816-8580, Japan. \\ ${ }^{4}$ Agriculture Microbiology, Agriculture Botany Department, Faculty of Agriculture, Kafrelsheikh University, Kafr El- \\ Sheikh, Egypt. \\ ${ }^{5}$ Department of Oceanography, University of Dhaka, Bangladesh. \\ *Corresponding author email: saha.baran.bidyut.213@m.kyushu-u.ac.jp
}

\begin{abstract}
Arsenic poisoning has been a great concern for the last two decades because of its extensive problems. Coagulation, ion exchange, ultrafiltration, and adsorption systems have been used for the removal of arsenic from polluted water. In this study, the biosorption process was used owing to eco-friendly, simplicity, biodegradable, and cost effectiveness. The uptake of arsenic from contaminated water by Ulva lactuca, Spirulina platensis, Chlorella vulgaris, orange peel, NZVI, zeolite, and composite of NZVI and algae was studied. This study observed that Chlorella vulgaris and iron coated Chlorella vulgaris absorb arsenic more effectively than other algae and iron coated algae. After 24 hours, Chlorella vulgaris and $\mathrm{Fe}$-coated Chlorella vulgaris absorbs $23 \%$ and $67 \%$ arsenic from contaminated water, respectively. The presented findings depicted the great potential of using bio-sorbents and the Fe-algae bio-composite for the removal of arsenic from contaminated aqueous solutions.
\end{abstract}

Keywords: Algae, Arsenate, Biosorption, Composite, NZVI

\section{INTRODUCTION}

Arsenic is an extremely poisonous heavy metal contained in the earth's crust that poses a serious threat to the environment and human health [1,2]. Arsenic is called the king of poisons. Marine sedimentary deposits, volcanic eruptions, natural erosion mechanisms, geothermal processes, and tectonic activity all contribute to its natural distribution into groundwater $[3,4]$. Moreover, arsenic adulteration occurs in groundwater due to human reckless doings, such as the use of agricultural pesticides, the extraction of excessive minerals from mining, and other anthropogenic activities $[5,6]$. Continuous exposure to arsenic contaminated water in human everyday life, such as preparing food, swallowing water, and irrigation, poses a risk to human health, including cancers of the skin, bladder, lung, kidney, breast, as well as cardiovascular disease, blackfoot diseases [7], hypertension, skin diseases (hyperkeratosis) and other ailments [8-11]. Because of its high toxicity to humans, the WHO (World Health Organization) and EPA (Environmental Protection Agency) have set $10 \mu \mathrm{gL}^{-1}$ as the maximum concentration of arsenic in drinking water.

Several removal technologies have been proposed in the literature for heavy metal removal from polluted water. Notable removal processes were precipitation, reverse osmosis, ion exchange, oxidation, permeable reactive barriers, coagulation and membrane filtration, and bioadsorption [12-14]. Almost all these methods are extremely expensive, non-eco-friendly, and complex operative. However, biosorption processes are promising, cost effective and environment friendly. This process removes heavy metals from water using biological resources such as algae [15], fungi, plant, bacteria, and genetic engineering breeding species. Because of its high heavy metal uptake capacity, algae biomass is one of the most promising kinds of biosorbent. Different types of algae have different affinities towards the similar metal, which are determined by the internal chemical structure of the algae. Several algae for example Chlorella vulgaris, Spirulina platensis, Caulerpa lentillifera, Ulva lactuca, Oscillatoria, Chlorella pyrenoidosa are efficient to eradicate heavy metals such as $\mathrm{As}, \mathrm{Cd}, \mathrm{Hg}$, and $\mathrm{Cr}(\mathrm{VI})$ from contaminated water. The main advantages of the algae are cost-effective, ameliorate for environment, and easy to cultivate [16].

The purpose of the study was to find the comprehensive investigation on adsorption of $\mathrm{As}(\mathrm{V})$ using algae, and other effective environment friendly biosorbent materials $[17,18]$. Furthermore, this study also examined the arsenate adsorption by composite materials of algae and Fe-nano particles. The biosorption of arsenate (As (V)) was measured using inductively coupled plasma mass spectrometry method (ICP-MS Agilent-7500cx). ICPMS Agilent $7500 \mathrm{cx}$ helium mode removes matrix induced interference and hydrogen mode eradicates molecular ions affected by argon. It ensures the highest performances with high consistency.

Table 1. Present National Standards for Arsenic in Drinking Water and Exposure Scenario

\begin{tabular}{ccccc}
\hline \hline Country & $\begin{array}{c}\text { Standard } \\
\text { value }(\mu \mathrm{g} / \mathrm{l})\end{array}$ & $\begin{array}{c}\text { Estimated affected } \\
\text { people (millions) }\end{array}$ & $\begin{array}{c}\text { Arsenic concentration in } \\
\text { different sources }(\mu \mathrm{g} / \mathrm{l})\end{array}$ & References \\
\hline Bangladesh & 50 & 85 & $\begin{array}{c}\text { Greater than } 10 \text { to less than } \\
2000\end{array}$ & $\begin{array}{c}\text { Edmunds W.M. et al. [19], Hossain } \\
\text { M.F. et al. [20] }\end{array}$ \\
India & 50 & 50 & $\begin{array}{c}\text { Greater than } 10 \text { to less than } \\
3200\end{array}$ & $\begin{array}{c}\text { Bhowmick S. et al. [21], Biswas A. } \\
\text { et al. [22] }\end{array}$ \\
\hline
\end{tabular}




\begin{tabular}{|c|c|c|c|c|}
\hline Nepal & 50 & 13 & $\begin{array}{l}\text { Greater than } 10 \text { to less than } \\
2600\end{array}$ & Thakur J. et al. [23] \\
\hline Pakistan & 50 & 13 & $\begin{array}{c}\text { Greater than } 10 \text { and greater } \\
\text { than } 2500\end{array}$ & Muhammad S. et al. [24] \\
\hline Canada & 25 & 1 & $\begin{array}{l}\text { Greater than } 10 \text { to less than } \\
2000\end{array}$ & Bondu R. et al. [25] \\
\hline USA & 10 & 0.3 & $\begin{array}{c}\text { Greater than } 10 \text { to less than } \\
3000\end{array}$ & Flanagan S.V. et al. [26] \\
\hline Argentina & 15 & 8 & $\begin{array}{c}\text { Greater than } 10 \text { and less } \\
\text { than } 2000\end{array}$ & Marta I. Liter [4] \\
\hline China & 10 & 20 & $\begin{array}{c}\text { Greater than } 5 \text { to less than } \\
500\end{array}$ & $\begin{array}{c}\text { Guo H. et al. [27], Chen L. et al. } \\
\text { [28] }\end{array}$ \\
\hline Australia & 7 & 0.5 & $\begin{array}{l}\text { Greater than } 10 \text { to less than } \\
3000\end{array}$ & Appleyard S.J. et al. [29] \\
\hline WHO & 10 & - & - & - \\
\hline EPA & 10 & - & - & - \\
\hline
\end{tabular}

\section{MATERIALS AND METHODS}

\subsection{Chemicals}

Sodium arsenate dibasic heptahydrate $\left(\mathrm{Na}_{2}\left(\mathrm{AsHO}_{4}\right) .7 \mathrm{H}_{2} \mathrm{O}\right.$, or $\mathrm{AsH}_{15} \mathrm{Na}_{2} \mathrm{O}_{11}$, Sigma-Aldrich company limited, Germany) were considered for the formulation of arsenate (As (V)), hydrochloric acid (HCL), Sodium Hydroxide $(\mathrm{NaOH}$, purity $97.0 \%)$ were procured from Sigma Aldrich (Germany) and were of analytical grade. In this experiment, deoxygenated deionized water was exploited to make all the solutions.

\subsection{Materials (biosorbent)}

Ulva lactuca was collected from Kagoshima university, Laboratory of Microbiology, Faculty of fisheries, Kagoshima prefecture, Japan. The biomass of Spirulina species was bought from Taobao marketplace, China. This fish food product comprises ten kinds of vitamins (for example, vitamin $\mathrm{A}, \mathrm{B}_{6}, \mathrm{~B}_{12}$ ) proteins, minerals, amino acids, and chlorophyll, which stimulates the growth of fish. Chlorella species was collected from the Agricultural Botany Department, Faculty of Agriculture, Kafrelsheikh University, Karh El-Sheikh in Egypt, as part of the project of algal biomass production for use as non-conventional fish feed; remediation of chemicals contaminated water; carbon dioxide capture; and biodiesel and omega-3 fatty acid production was funded by National Strategy for Genetic Engineering and Biotechnology Phase (III). One-gram iron nanoparticles (NZVI) was prepared using $0.092 \mathrm{M}$ ferric chloride hexahydrate and $0.58 \mathrm{M}$ sodium borohydride solution following the optimized synthesis approach previously reported [30-32]. Mixture was conducted under anaerobic conditions. During the synthesis process, $30^{\circ} \mathrm{C}$ temperature was maintained. The black particles were isolated by vacuum filtration through a 0.45 micrometer cellulose membrane filter and washed double times by deionized water. Then the sample was used in the experiments. Zeolite was purchased from Sigma-Aldrich Co., Germany.

\subsection{Stock solution:}

One liter arsenic (V) stock solution was prepared by dissolving $83.3 \mathrm{mg} \mathrm{Na} \mathrm{HAsO}_{4} .7 \mathrm{H}_{2} \mathrm{O}$ in $100 \mathrm{ml}$ deionized water. $50 \mathrm{ml}$ nitric acid was added to the solution while mixing (common concentrations is $5 \% \mathrm{v} / \mathrm{v}$, to keep As
(V) in ionized form and to prevent transformation to As (III) or to stock on the wall of the conical flask). After that, the solution was diluted to $1000 \mathrm{ml}$ with deionized water. Arsenic (V) solution was stirred thoroughly and then kept in the refrigerator. The $\mathrm{pH}$ of the arsenic solution was maintained to 5.5 using $\mathrm{HCl}$ and $\mathrm{NaOH}$.

2.4 Biosorption process of metal ions (As) by Algae, NZVI, zeolite and new composite

The experiments on bio-adsorption properties were operated for the functionalized Ulva lactuca, nano zero valent iron (NZVI), zeolite, live and dead (powder) Chlorella Vulgaris, Spirulina platensis, orange peel (result is not included), and Ulva lactuca. The batch experiments were performed in conical flasks comprising $100 \mathrm{ml}$ of $\mathrm{As}(\mathrm{V})$ solution in a magnetic stir shaker under $1000 \mathrm{rpm}$ at $25^{\circ} \mathrm{C}$ and initial $\mathrm{pH}$ was 5.5. At various time intervals, $2 \mathrm{ml}$ samples were collected over $24 \mathrm{~h}$ reaction time and filtered with 0.45 micrometer membrane for analysis. The following equations were used to calculate removal efficiency and adsorption capacity.

$$
\begin{aligned}
& q=\frac{\left(C_{0}-C_{e}\right)}{m} V \\
& \operatorname{Re}(\%)=\frac{C_{0}-C_{e}}{C_{0}} \times 100
\end{aligned}
$$

where $\mathrm{q}$ indicates the adsorption capacity, $C_{0}$ is the initial concentration of arsenic, $C_{e}$ is concentration of arsenic at equilibrium states, $\mathrm{m}$ is the mass of the sorbent dose, and Re indicates the removal efficiency.

\section{RESULTS AND DISCUSSION}

Assessing and observing arsenic (V) content in drinking water is tremendously significant because 500 million people around the world are affecting by its impact [33]. Around $48 \%$ of the total population was affected by groundwater arsenic in Bangladesh [34]. Table 1 illustrated the arsenic contamination level, affected people by arsenic, and standard value in different countries. There is no known effective treatment or medicine for arsenic toxicity, affected people can recover from the toxicity by consuming healthy food and drinking arsenic free water. Proper cost-effective water treatment along with awareness about arsenic is effective to solve the present crisis. Biosorption of arsenic using 
algae is one of the most reliable, cost-effective, and environment friendly process.

For analyzing the biosorption of arsenic, it is an important issue to find the calibration curve in measurement procedures. This curve established the relationship between the calibration standard values and experimental data. The calibration curve for arsenic (V) was functioned using a stock solution. Ten working standard solutions was prepared with $0.25,0.5,1,3,5$, 10, 30, 50, 70, and $100 \mathrm{ppb}$. Arsenic calibration curve was shown in Fig. 1. In this study, following calibration curve was used for calculation of removal efficiency of arsenic from contaminated water.

$Y=2349.1 X+58.654$

For the calibration curve, we found that the R-squared value is 1 in this study. The following expression is used for finding the R-squared value.

$R^{2}=\frac{\text { Variance explained by the corresponding model }}{\text { Total }}$

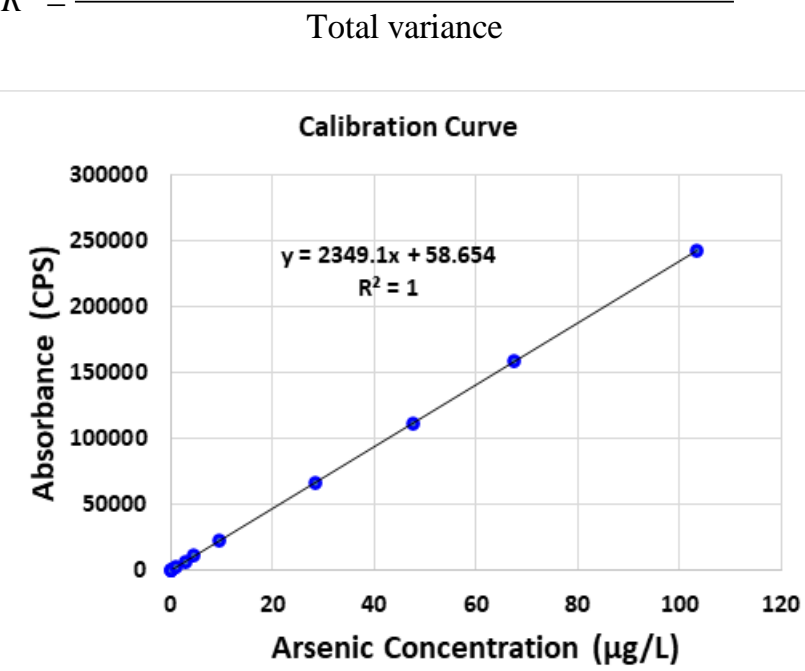

Fig. 1. Arsenic calibration curve determined using ICPMS 7500cx.

In this study, the tests were accomplished for different dosage algae concentration. $1 \mathrm{~g} / 1,5 \mathrm{~g} / \mathrm{l}, 10 \mathrm{~g} / \mathrm{l}, 15 \mathrm{~g} / \mathrm{l}$ and $20 \mathrm{~g} / \mathrm{l}$ dosages of Spirulina platensis, Ulva lactuca, Chlorella vulgaris, and other composite materials with different concentration of Arsenic (V). All tests were conducted at $\mathrm{pH}$ 5.5. In the previous literature, it was found that if $\mathrm{pH}>5.5$, then arsenic and chromium adsorption were decreased [35]. Temperature and $\mathrm{pH}$ are decisive factors in biosorption investigations because they influence the solubility of metal. For biosorption study, we use different initial dosage of algae sample and other biosorbent composite materials. Fig. 2 showed the circumstances before the experiment and during the test of arsenic adsorption.

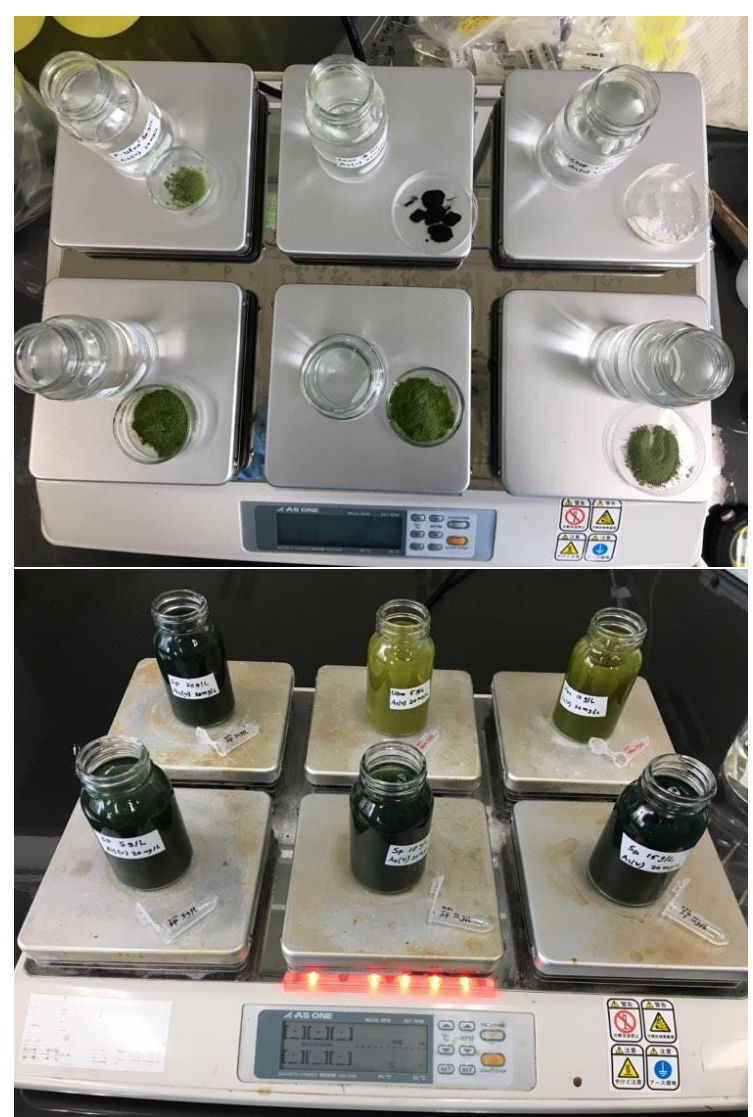

Fig. 2. Experiment of As(V) biosorption using algae before experiment (upper figure) and during experiment (lower figure).

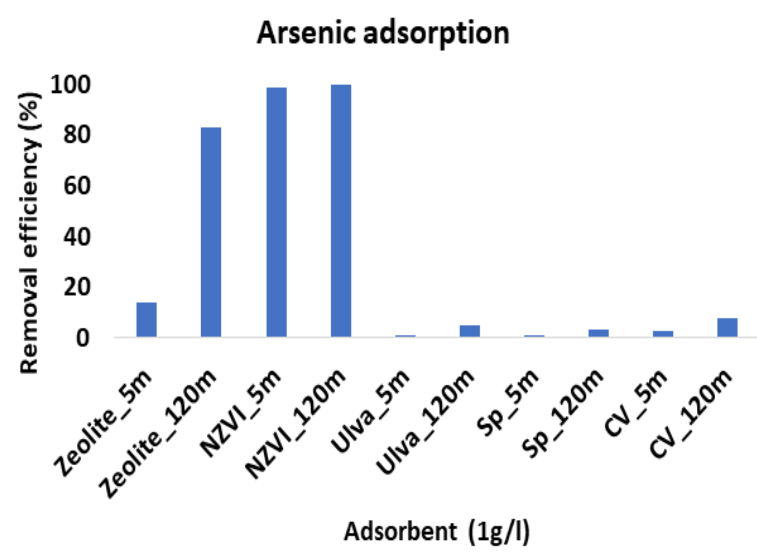

Fig. 3. Arsenic adsorption using different adsorbent materials $(1 \mathrm{~g} / \mathrm{l})$.

25

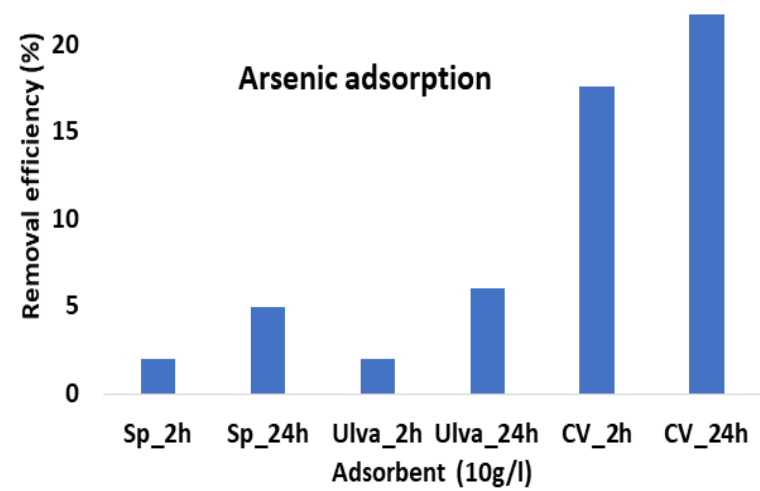

Fig. 4. Arsenic adsorption using different algae (10g/l) with different adsorption times. 


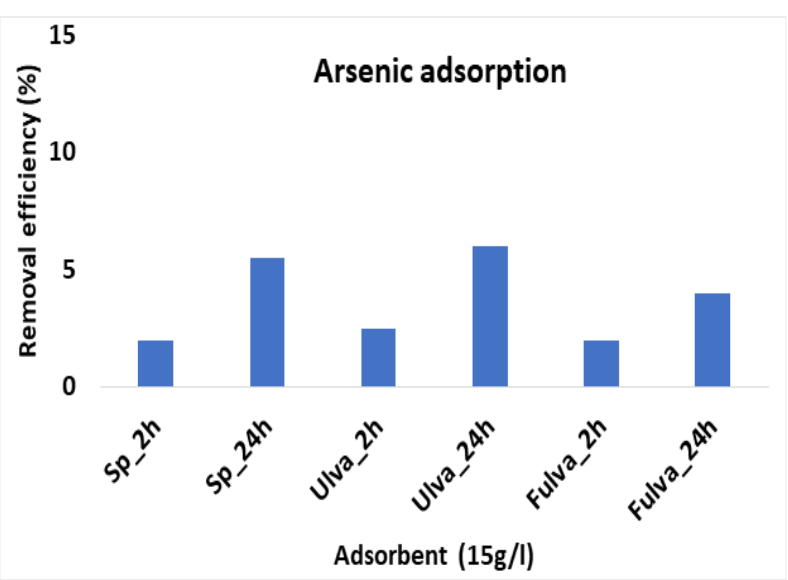

Fig. 5. Arsenic adsorption using different algae (15g/l) with different adsorption times.

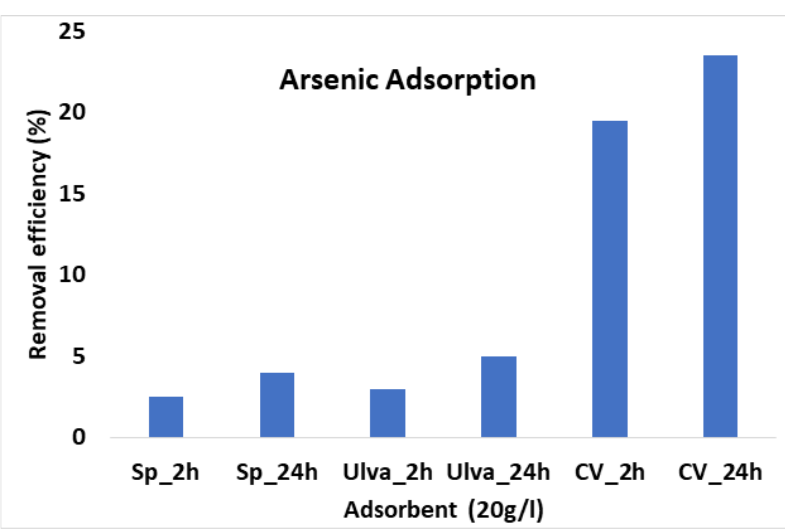

Fig. 6. Arsenic adsorption using different algae (20g/l) with different adsorption times.

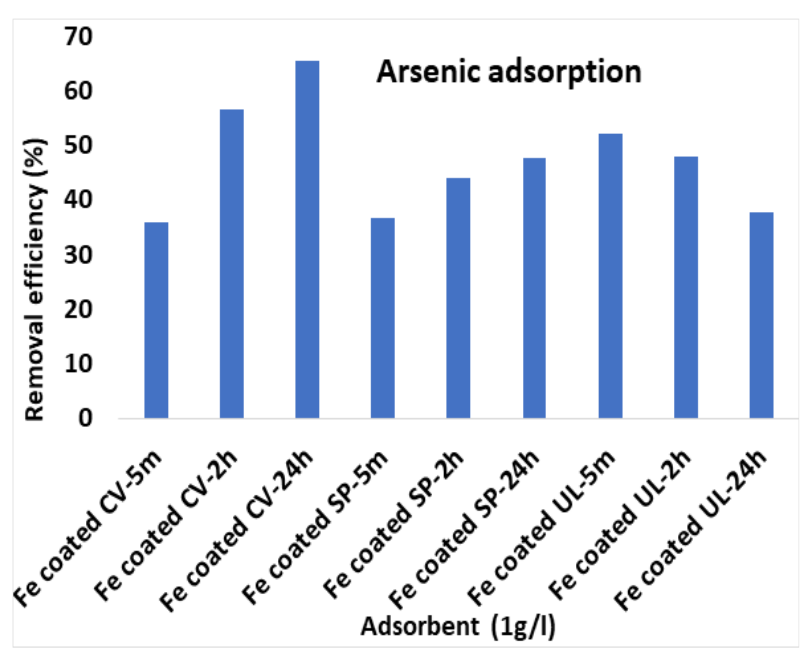

Fig. 7. Arsenic adsorption using algae composite materials $(1 \mathrm{~g} / \mathrm{l})$.

Fig. 3 to Fig. 6 describes the arsenic adsorption for different dosage of algae, iron nano particles, and zeolite. In Fig. 3, the usage dosage of Ulva lactuca, Spirulina platensis, Chlorella vulgaris, zeolite, and NZVI are $1 \mathrm{~g} / \mathrm{l}$ for arsenic adsorption. It is observed that NZVI adsorbed approximately $99 \%$ arsenic after 5 minutes, zeolite adsorbed about $85 \%$ but pure algae did not show good adsorption. The main reason for the rapid and efficient removal of $\mathrm{As}(\mathrm{V})$ by NZVI is the involvement of different removal mechanisms within the reaction, including the electrostatic attraction of the negatively charged arsenate species to the positively charged surface of NZVI at pH 5.5 (point of zero charge was reported to be at $\mathrm{pH} 8.2$ ) [36,37]. Moreover, the possible reduction of $\mathrm{As}(\mathrm{V})$ to $\mathrm{As}(\mathrm{III})$ via the released electron from the iron core, and hence the involvement of precipitation and coprecipitation of $\mathrm{As}$ (III) with $\mathrm{Fe}(\mathrm{II})$ and $\mathrm{Fe}(\mathrm{III})$ on the surface. While the porous structure in addition to the high ion exchange ability were the main $\mathrm{As}(\mathrm{V})$ removal mechanisms by zeolite. When we increase the dosage of algae for example 10g/l, $15 \mathrm{~g} / \mathrm{l}$, and $20 \mathrm{~g} / \mathrm{l}$ (Fig. 4, Fig.5, and Fig.6), only Chlorella Vulgaris adsorbed about 24\% arsenic after 24 hours for $20 \mathrm{~g} / \mathrm{l}$. In this study, algae dosage increases due to its environmentally friendly nature, cost effective and easy to cultivate. Although the dosage of algae has been increased, the amount of arsenic adsorption has not increased significantly. NZVI absorbed approximately $100 \%$ arsenic though has some problems such as poor mobility, particles agglomeration, costly, and limited suspension stability. For this reason, we prepare composite materials using algae (for example, Spirulina platensis, Ulva lactuca, and Chlorella vulgaris) and NZVI in this study.

To eradicate the disadvantage of nano zero valent iron, represented in the strong tendency of the particles to aggregate, poor stability in aqueous suspensions, and the rapid corrosion of the iron core, composite materials have been made using algae and NZVI. In this research, $40 \%$ Fe-nano particles and $60 \%$ algae (Spirulina platensis, Chlorella vulgaris, and Ulva Lactuca) was mixing physically using mortar and shell. $1 \mathrm{~g} / \mathrm{l}$ composite materials of algae and NZVI were used for this experiment to adsorb arsenic. In Fig.7, it is observed that Fe coated Chlorella vulgaris (Fe coated CV) increases the adsorption of arsenic corresponding with time. Fe coated $\mathrm{CV}$ showed $36 \%, 55 \%$, and $67 \%$ removal efficiency after 5 minutes, 2 hours, and 24 hours respectively. Fe coated Spirulina platensis (Fe coated SP) also showed similar trends for arsenic adsorption. But $\mathrm{Fe}$ coated SP adsorbed about $50 \%$ arsenic from the sample after 24 hours. Fe coated Ulva Lactuca (Fe coated UL) showed surprising behavior for arsenic adsorption. Fe coated UL decreases the adsorption of arsenic corresponding with increasing time. Fe coated UL showed $52 \%, 48 \%$, and $38 \%$ removal efficiency after 5 minutes, 2 hours, and 24 hours respectively.

\section{CONCLUSION}

In this research, comprehensive approach was adopted to analysis the uptake of arsenic from contaminated water by Chlorella vulgaris, Ulva lactuca, Spirulina platensis, orange peel, nano-zero valent iron, zeolite, and composite of algae and iron nano particles. From this study, we found that Chlorella vulguris and Fe coated Chlorella vulgaris are more efficient than other algae to absorb arsenic (V). In the future, we will observe the arsenic adsorption by algae and other efficient environment-friendly materials and their chemical compositions.

\section{REFERENCES}

[1] J. Bundschuh, M.A. Armienta, N. Morales-Simfors, M.A. Alam, D.L. López, V. Delgado Quezada, S. Dietrich, J. Schneider, J. Tapia, O. Sracek, E. Castillo, L.M. Marco Parra, M. Altamirano 
Espinoza, L.R. Guimarães Guilherme, N.N. Sosa, N.K. Niazi, B. Tomaszewska, K. Lizama Allende, K. Bieger, D.L. Alonso, P.F.B. Brandão, P. Bhattacharya, M.I. Litter, A. Ahmad, Arsenic in Latin America: New findings on source, mobilization and mobility in human environments in 20 countries based on decadal research 20102020, Critical Reviews in Environmental Science and Technology. (2020) 1-139. doi:10.1080/10643389.2020.1770527.

[2] D. Sinha, P. Prasad, Health effects inflicted by chronic low-level arsenic contamination in groundwater: A global public health challenge, Journal of Applied Toxicology. 40 (2020) 87-131. doi:10.1002/jat.3823.

[3] N. Morales-Simfors, J. Bundschuh, I. Herath, C. Inguaggiato, A.T. Caselli, J. Tapia, F.E.A. Choquehuayta, M.A. Armienta, M. Ormachea, E. Joseph, D.L. López, Arsenic in Latin America: A critical overview on the geochemistry of arsenic originating from geothermal features and volcanic emissions for solving its environmental consequences, Science of the Total Environment. $716 \quad 135564$. doi:10.1016/j.scitotenv.2019.135564.

[4] M.I. Litter, A.M. Ingallinella, V. Olmos, M. Savio, G. Difeo, L. Botto, E.M.F. Torres, S. Taylor, S. Frangie, J. Herkovits, I. Schalamuk, M.J. González, E. Berardozzi, F.S. García Einschlag, P. Bhattacharya, A. Ahmad, Arsenic in Argentina: Technologies for arsenic removal from groundwater sources, investment costs and waste management practices, Science of the Total Environment. $\quad 690 \quad$ (2019) 778-789. doi:10.1016/j.scitotenv.2019.06.358.

[5] P. Knappett, K.D. Myers, K. Kwak, L. Wang, M.B. Cardenas, S. Datta, A. Hosain, K.M. Ahmed, S.H. Ahkter, Sources and Sinks of Arsenic in Riverbanks along the Meghna River, Bangladesh, in: AGU Fall Meeting Abstracts, 2020: pp. H13005 .

[6] B. Huhmann, C.F. Harvey, A. Uddin, I. Choudhury, K.M. Ahmed, J.M. Duxbury, T. Ellis, A. Van Geen, Inversion of High-Arsenic Soil for Improved Rice Yield in Bangladesh, Environmental Science and Technology. $53 \quad$ (2019) 3410-3418. doi:10.1021/acs.est.8b06064.

[7] K.L. CHEN, H. WU, Epidemiologic studies on blackfoot disease. 2. A study of source of drinking water in relation to the disease., Taiwan Yi Xue Hui $\mathrm{Za}$ Zhi. Journal of the Formosan Medical Association. 61 (1962) 611-618.

[8] K.M. Khan, R. Chakraborty, J. Bundschuh, P. Bhattacharya, F. Parvez, Health effects of arsenic exposure in Latin America: An overview of the past eight years of research, Science of the Total Environment. $\quad 710 \quad$ (2020) 136071. doi:10.1016/j.scitotenv.2019.136071.

[9] B. Tomaszewska, J. Bundschuh, L. Pająk, M. Dendys, V. Delgado Quezada, M. Bodzek, M.A. Armienta, M.O. Muñoz, A. Kasztelewicz, Use of low-enthalpy and waste geothermal energy sources to solve arsenic problems in freshwater production in selected regions of Latin America using a process membrane distillation - Research into model solutions, Science of the Total Environment. 714 (2020). doi:10.1016/j.scitotenv.2020.136853.

[10] M.R. Khan, H.A. Michael, B. Nath, B.L. Huhmann, C.F. Harvey, A. Mukherjee, I. Choudhury, M. Chakraborty, M.S. Ullah, K.M. Ahmed, S.L. Goodbred, P. Schlosser, B.C. Bostick, B.J. Mailloux, T. Ellis, A. van Geen, High-Arsenic Groundwater in the Southwestern Bengal Basin Caused by a Lithologically Controlled Deep Flow System, Geophysical Research Letters. 46 (2019) 13062-13071. doi:10.1029/2019GL084767.

[11] M.A. Rahman, A. Rahman, M.Z.K. Khan, A.M.N. Renzaho, Human health risks and socio-economic perspectives of arsenic exposure in Bangladesh: A scoping review, Ecotoxicology and Environmental Safety. $\quad 150 \quad$ (2018) 335-343. doi:10.1016/j.ecoenv.2017.12.032.

[12] A. Ahmad, S. Rutten, L. de Waal, P. Vollaard, C. van Genuchten, H. Bruning, E. Cornelissen, A. van der Wal, Mechanisms of arsenate removal and membrane fouling in ferric based coprecipitationlow pressure membrane filtration systems, Separation and Purification Technology. 241 (2020) 116644. doi:10.1016/j.seppur.2020.116644.

[13] I. Akin, G. Arslan, A. Tor, M. Ersoz, Y. Cengeloglu, Arsenic(V) removal from underground water by magnetic nanoparticles synthesized from waste red mud, Journal of Hazardous Materials. 235-236 (2012) 62-68. doi:10.1016/j.jhazmat.2012.06.024.

[14] H. Hernández-Flores, N. Pariona, M. Herrera-Trejo, H.M. Hdz-García, A.I. Mtz-Enriquez, Concrete/maghemite nanocomposites as novel adsorbents for arsenic removal, Journal of Molecular Structure. 1171 (2018) 9-16. doi:10.1016/j.molstruc.2018.05.078.

[15] A.H. Sayed, D. Kitamura, S. Oda, S. Kashiwada, H. Mitani, Cytotoxic and genotoxic effects of arsenic on erythrocytes of Oryzias latipes: Bioremediation using Spirulina platensis, Journal of Trace Elements in Medicine and Biology. 55 (2019) 8288. doi:10.1016/j.jtemb.2019.06.007.

[16] M.S. Islam, M.M. Rahman, B.B. Saha, Full Factorial Experimental Design for Growth of Spirulina Platensis and Valuable Products Enhancement, in: Proceedings of International Exchange and Innovation Conference on Engineering \& Sciences (IEICES), 2020: pp. 299304.

[17] M. Rahim, M.R.H. Mas Haris, Application of biopolymer composites in arsenic removal from aqueous medium: A review, Journal of Radiation Research and Applied Sciences. 8 (2015) 255-263. doi:10.1016/j.jrras.2015.03.001.

[18] K. Banerjee, G.L. Amy, M. Prevost, S. Nour, M. Jekel, P.M. Gallagher, C.D. Blumenschein, Kinetic and thermodynamic aspects of adsorption of arsenic onto granular ferric hydroxide (GFH), Water Research. 42 (2008) 3371-3378. doi:10.1016/j.watres.2008.04.019.

[19] W.M. Edmunds, K.M. Ahmed, P.G. Whitehead, A review of arsenic and its impacts in groundwater of the Ganges-Brahmaputra-Meghna delta, Bangladesh, Environmental Sciences: Processes and Impacts. 17 (2015) 1032-1046. doi:10.1039/c4em00673a. 
[20] M.F. Hossain, Arsenic contamination in Bangladesh - An overview, Agriculture, Ecosystems and Environment. 113 (2006) 1-16. doi:10.1016/j.agee.2005.08.034.

[21] S. Bhowmick, S. Pramanik, P. Singh, P. Mondal, D. Chatterjee, J. Nriagu, Arsenic in groundwater of West Bengal, India: A review of human health risks and assessment of possible intervention options, Science of the Total Environment. 612 (2018) 148169. doi:10.1016/j.scitotenv.2017.08.216.

[22] A. Biswas, S. Biswas, S.C. Santra, Risk from winter vegetables and pulses produced in arsenic endemic areas of Nadia district: Field study comparison with market basket survey, Bulletin of Environmental Contamination and Toxicology. 88 (2012) 909-914. doi:10.1007/s00128-012-0569-z.

[23] J.K. Thakur, R.K. Thakur, A.L. Ramanathan, M. Kumar, S.K. Singh, Arsenic contamination of groundwater in Nepal-An overview, Water (Switzerland). $\quad 3 \quad$ (2011) 1-20. doi:10.3390/w3010001.

[24] S. Muhammad, M. Tahir Shah, S. Khan, Arsenic health risk assessment in drinking water and source apportionment using multivariate statistical techniques in Kohistan region, northern Pakistan, Food and Chemical Toxicology. 48 (2010) 28552864. doi:10.1016/j.fct.2010.07.018.

[25] R. Bondu, V. Cloutier, E. Rosa, M. Benzaazoua, Mobility and speciation of geogenic arsenic in bedrock groundwater from the Canadian Shield in western Quebec, Canada, Science of the Total Environment. $574 \quad$ (2017) 509-519. doi:10.1016/j.scitotenv.2016.08.210.

[26] S. V. Flanagan, R.G. Marvinney, Y. Zheng, Influences on domestic well water testing behavior in a Central Maine area with frequent groundwater arsenic occurrence, Science of the Total Environment. 505 (2015) 1274-1281. doi:10.1016/j.scitotenv.2014.05.017.

[27] H. Guo, D. Wen, Z. Liu, Y. Jia, Q. Guo, A review of high arsenic groundwater in Mainland and Taiwan, China: Distribution, characteristics and geochemical processes, Applied Geochemistry. 41 (2014)

196-217. doi:10.1016/j.apgeochem.2013.12.016.

[28] C. Luo, J. Routh, D. Luo, L. Wei, Y. Liu, Arsenic in the Pearl River Delta and its related waterbody, South China: occurrence and sources, a review, Geoscience Letters. 8 (2021). doi:10.1186/s40562021-00185-9.

[29] S.J. Appleyard, J. Angeloni, R. Watkins, Arsenicrich groundwater in an urban area experiencing drought and increasing population density, Perth, Australia, Applied Geochemistry. 21 (2006) 83-97. doi:10.1016/j.apgeochem.2005.09.008.

[30] I. Maamoun, R. Eljamal, O. Falyouna, K. Bensaida, Y. Sugihara, O. Eljamal, Insights into kinetics, isotherms and thermodynamics of phosphorus sorption onto nanoscale zero-valent iron, Journal of Molecular Liquids. $328 \quad$ (2021) 115402. doi:10.1016/j.molliq.2021.115402.

[31] I. Maamoun, O. Eljamal, T. Shubair, H. Noutsuka, B.B. Saha, N. Matsunaga, Integrating nano-scale zero valent iron (nZVI) in phosphorus removal from aqueous solution through porous media: packed-column experiment, Proceedings of International Exchange and Innovation Conference on Engineering \& Sciences (IEICES). 3 (2017) 2530.

[32] R. Eljamal, O. Eljamal, I. Maamoun, G. Yilmaz, Y. Sugihara, Enhancing the characteristics and reactivity of nZVI: Polymers effect and mechanisms, Journal of Molecular Liquids. 315 (2020) 113714. doi:10.1016/j.molliq.2020.113714.

[33] E. Shaji, M. Santosh, K. V. Sarath, P. Prakash, V. Deepchand, B. V. Divya, Arsenic contamination of groundwater: A global synopsis with focus on the Indian Peninsula, Geoscience Frontiers. 12 (2021) 101079. doi:10.1016/j.gsf.2020.08.015.

[34] M. Ashraf Ali, International Review for Environmental Strategies Special Feature on Groundwater Management and Policy Arsenic Contamination of Groundwater in Bangladesh, 2006.

[35] I. Michalak, A. Zielinska, K. Chojnacka, J. Matula, Biosorption of $\mathrm{Cr}$ ( III ) by Microalgae and Macroalgae : Equilibrium of the Process, American Journal of Agricultural and Biological Sciences. 2 (2007) 284-290.

[36] I. Maamoun, O. Eljamal, R. Eljamal, O. Falyouna, Y. Sugihara, Promoting aqueous and transport characteristics of highly reactive nanoscale zero valent iron via different layered hydroxide coatings, Applied Surface Science. 506 (2020) 145018. doi:10.1016/j.apsusc.2019.145018.

[37] R. Eljamal, I. Kahraman, O. Eljamal, I.P. Thompson, I. Maamoun, G. Yilmaz, Impact of nZVI on the formation of aerobic granules, bacterial growth and nutrient removal using aerobic sequencing batch reactor, Environmental Technology and Innovation. 19 (2020) 100911. doi:10.1016/j.eti.2020.100911. 